\title{
Nutritive value and anthelmintic effect of sainfoin pellets fed to experimentally infected growing rabbits
}

\author{
H. Legendre ${ }^{1,2,3}$, H. Hoste ${ }^{2,3}$ and T. Gidenne ${ }^{1 \dagger}$ \\ ${ }^{1}$ GenPhySE, Université de Toulouse, INRA, INPT, ENVT, 31326 Castanet Tolosan, France; ${ }^{2}$ UMR 1225 IHAP INRA/ENVT, 23 Chemin des Capelles, 31076 Toulouse, \\ France, ${ }^{3}$ Université de Toulouse, INP-ENVT, 23 Chemin des Capelles, 31076 Toulouse, France
}

(Received 28 September 2016; Accepted 25 November 2016; First published online 20 February 2017)

\begin{abstract}
Alternative strategies to synthetic chemical drugs are needed in livestock and are a key issue in organic farming today. This study aimed at examining the potentialities of sainfoin, a legume rich in condensed tannins, as a nutraceutical that combines nutritive and antiparasitic effects in rabbits. To test the effect of infection with a helminth (I: infected groups; Nl: not infected groups) and the effect of substituting $40 \%$ of the alfalfa in a control diet (C) with sainfoin (diet S), four groups of 16 weaned rabbits were arranged according to a $2 \times 2$ bifactorial design. The sainfoin diet differed from the control by its tannin concentration $(1.8 \% \mathrm{v}$. $1.0 \%$ tannic acid equivalent) and its $A D L$ concentration ( $84 \mathrm{v} .43 \mathrm{~g} / \mathrm{kg}$ ). For each diet, 16 rabbits were infected with 2125 thirdstage larvae of Trichostrongylus colubriformis. Growth, feed intake, feed conversion ratio and nematode faecal egg counts (FECS) were controlled for 6 weeks. A digestibility trial was performed. After necropsy, adult worms and eggs in utero per female were counted and egg-hatching rate calculated. Growth tended to be lower for $S$ groups than for $C$ groups (38.2 v. $39.5 \mathrm{~g} /$ day; $\mathrm{P}=0.06)$. Feed intake was higher for $S$ groups compared with $C$ groups $(+5.2 \mathrm{~g}$ dry matter/day; $\mathrm{P}<0.01)$, as was the feed conversion ratio (3.2 v. 2.9; $\mathrm{P}<0.001)$, probably in relation to the dietary ADL level. Protein digestibility was reduced in $S$ groups compared with $C$ groups $(-6.0$ points; $\mathrm{P}<0.001)$, probably associated with the effect of the tannin concentration. Digestibility of hemicelluloses was reduced in infected rabbits compared with non-infected ones $(-5$ points; $\mathrm{P}=0.01)$. Using the substitution method, the digestible energy of dehydrated sainfoin pellets used as raw material was calculated at $11.12 \mathrm{MJ} / \mathrm{kg}$ and digestible proteins at $110 \mathrm{~g} / \mathrm{kg}$. The infection did not produce any clinical signs of digestive disorders. No differences were observed according to the diet, neither in the number of adult worms (972; $\mathrm{P}=0.50)$, the number of eggs in utero per female $(14 ; \mathrm{P}=0.95)$, nor FEC (400 eggs/g; $\mathrm{P}=0.57$ ). In contrast, the rate of faecal egg hatching in the $S$ group tended to be lower than in the control $(58.3 \%$ v. $85.2 \% ; \mathrm{P}=0.08)$. In conclusion, sainfoin seems to fit nutritive requirements for rabbits, supplies a large quantity of fibre and particularly lignins, and limits the development of nematode eggs in faeces.
\end{abstract}

Keywords: rabbit, sainfoin, condensed tannin, nematode, nutraceutical

\section{Implications}

Strategies to control worms without using synthetic chemical drugs are increasingly needed because of the development of resistance to chemical drugs in pathogens. In addition, in organic farming (OF) systems, the use of chemical drugs to control worms is usually avoided. In ruminants, the concept of nutraceuticals (plants that combine both nutritive value and beneficial effects on health) has emerged as an alternative strategy to control nematodes (Hoste et al., 2015), particularly through the use of forages that contain tannins, such as sainfoin. The interest of such an option in rabbit has remained unexplored. Furthermore, local alternatives to alfalfa meal for rabbit feeding are in great demand worldwide.

\footnotetext{
${ }^{\dagger}$ E-mail: thierry.gidenne@inra.fr
}

This article presents an original scientific study aimed at evaluating the nutritive value of dehydrated sainfoin for the growing rabbit. In the context of organic rabbit farming, it also provides results on the possible anthelmintic effects of condensed tannins (CTs) in experimentally infected rabbits.

\section{Introduction}

Health management is one of the main issues for rabbit breeders in France. The use of antibiotics, coccidiostatics and anthelmintic drugs to control diseases in rabbit meat production is increasingly questioned by consumers due to the possible harmful effects of chemical residues from drugs in the environment. In addition, the demand for products from rabbits bred according to OF specifications is increasing (Martin et al., 2016). Organic specifications require that 
rabbits have a link to the soil. Consequently, in addition to coccidian infections, rabbits bred in OF systems are more exposed to the free-living stages of helminths and, particularly, to gastrointestinal nematodes (GINs). On the other hand, OF rules severely restrict the use of synthetic chemical drugs to control pathogens. Therefore, the need to explore non-chemical alternative strategies to control parasites in rabbits is now a priority. One of the potential alternative strategies, inspired by research performed in small ruminants, is the use of CT-containing plants (in particular, legumes) as nutraceuticals (Hoste et al., 2015). Moreover, alternatives to the use of alfalfa meal as a combined source of fibre and proteins for growing rabbits are being explored in many countries today in order to reduce importations.

Sainfoin (Onobrychis viciifolia) has been widely explored as a model of a tannin-containing legume used as a nutraceutical in small ruminants. It is also a good candidate for rabbit feed as it contains high ADF and ADL levels associated with a high level of protein. This legume was historically used to feed rabbits but, to our knowledge, studies dealing with the potential effect of sainfoin as a nutraceutical in rabbit are still lacking.

Trichostrongylus colubriformis is a common nematode, a parasite of small ruminants, which could be experimentally used to infect the European rabbit (Oryctolagus cuniculus) (Audebert et al., 2003). It has been considered as a model of the specific nematode of lagomorphs, Trichostrongylus retortaeformis, as well as an experimental model to examine the host-nematode interactions in the case of infections with Trichostrongylus sp. (Hoste et al., 1988). Sainfoin and its contained CTs could disturb the life cycle of $T$. colubriformis, as previously shown in vitro and in vivo in ruminants (Paolini et al., 2003 and 2004).

Thus, our study aimed (i) at measuring the nutritive value of sainfoin for the growing rabbit by analysing the effect of alfalfa replacement by sainfoin in a pelleted balanced diet on digestion and performance, and (ii) at determining the effect of sainfoin intake during an experimental infection of rabbits with $T$. colubriformis.

\section{Material and methods}

\section{Animals and experimental design}

The experiment was carried out within the framework of the Regional Ethical Committee on Animal Experimentation of the Midi-Pyrénées (France) at ENVT, and concerned 64 rabbits of the INRA 1777 strain, from weaning (28 days old) to slaughter (73 days). Rabbits used in this experiment were obtained from specific pathogen-free (SPF, including coccidia) mothers, and bred from birth to weaning on a coccidianfree farm. During the trial, rabbits were no longer maintained in SPF conditions but, instead, in a specific high hygiene breeding room adapted for complete cleaning. In order to test the effect of infection and the effect of sainfoin incorporation, 64 rabbits were randomly divided into four groups according to a bifactorial design $(2 \times 2)$, and the groups were balanced according to weight at weaning and litter origin.
The four groups, composed of 16 rabbits each, consisted of infected control (IC), infected sainfoin (IS), non-infected control and non-infected sainfoin (NIS). Two rabbits were housed per cage. According to the experimental group, the rabbits were fed either a pelleted experimental control diet (alfalfa base; Table 1) or a sainfoin diet in which $40 \%$ of the control diet (except minerals) were substituted with dehydrated pellets of sainfoin (Perly variety) provided by MG2Mix-Multifolia (Chateaubourg, France). Consequently, we were able to calculate the nutritive value of the dehydrated sainfoin - namely, the digestible energy and protein content (DE and DP) (Villamide et al., 2001) - by comparison with the control. Diets were formulated to have similar values in crude ash, CP, NDF and $D E$, and to cover the requirements for the growing rabbit (Gidenne et al., 2015). Both diets were free of any chemical anthelminthic or coccidiostatic drug. Animals were fed ad libitum throughout the experiment. The weight and health status of animals were controlled on a weekly basis, as was their feed intake.

\section{Digestibility trial and chemical analyses}

For the digestibility trial, faeces were collected according to the 'European' Reference method (Perez et al., 1995), between 60 and 64 days of age (corresponding to D21 and D25 post-infection (DPI), D0 being the day of experimental infection with $T$ colubriformis). Rabbits were allowed a 4-week period of adaptation to the experimental diet and nematode challenge before total faecal collection. A device was designed to collect the total amount of faeces excreted by the two rabbits per cage (without urine contamination). Rabbit growth and feed consumption per cage (i.e. for two rabbits) were controlled for the 5 days of the digestibility trial.

Dry matter (DM) contents of the feed were determined at $103^{\circ} \mathrm{C}$ for $24 \mathrm{~h}$ and ash at $550^{\circ} \mathrm{C}$ for $5 \mathrm{~h}$. Fibrous fractions (NDF, ADF and ADL) were carried out according to the sequential method of Van Soest et al. (1991), nitrogen was measured according to the Dumas combustion method and energy according to adiabatic combustion. We calculated hemicelluloses as NDF-ADF.

Tannins were analysed by the method of Folin-Ciocalteu (Makkar, 2003; Inovalys Laboratory, Nantes, France). The biological activity of tannins was assessed by the method of radial diffusion using bovine serum albumin (BSA) medium (Hagerman and Butler, 1978). As sainfoin contains no hydrolysable tannins (Marais et al., 2000), the amount of CTs was considered to be equal to the total tannins

\section{Parasitological techniques}

Four days after weaning, rabbits in groups IC and IS were orally infected with 2125 infective, third-stage larvae (L3) of $T$. colubriformis. This date was counted as D0 of infection. The larvae were collected from one donor sheep in the Hellenic Agriculture Organisation (Veterinary Research Institute of Thessaloniki, Greece), sent to France and maintained for 8 weeks at $4^{\circ} \mathrm{C}$ before being used to infect the rabbits. Faecal samples were collected weekly at the beginning of the 
Table 1 Ingredients and chemical composition of the experimental diets

\begin{tabular}{|c|c|c|c|}
\hline & $\begin{array}{l}\text { Control } \\
\text { (C) }\end{array}$ & $\begin{array}{l}\text { Sainfoin } \\
\text { (S) }\end{array}$ & $\begin{array}{l}\text { Sainfoin, dehydrated } \\
\text { pellets (raw material) }\end{array}$ \\
\hline \multicolumn{4}{|l|}{ Ingredients (\%) } \\
\hline Dehydrated sainfoin & & 39.6 & \\
\hline Dehydrated alfalfa & 40.0 & 24.0 & \\
\hline Wheat & 16.0 & 9.6 & \\
\hline Wheat bran & 7.0 & 4.2 & \\
\hline Beet pulp & 10.0 & 6.0 & \\
\hline Soyabean meal & 6.0 & 3.6 & \\
\hline Sunflower meal & 11.9 & 7.1 & \\
\hline Wheat straw & 8.0 & 4.8 & \\
\hline $\begin{array}{l}\text { Mineral and vitamin } \\
\text { premix }\end{array}$ & 1.1 & 1.1 & \\
\hline \multicolumn{4}{|l|}{$\begin{array}{l}\text { Chemical composition } \\
\text { (g/kg as fed) }\end{array}$} \\
\hline Dry matter & 910 & 901 & 857 \\
\hline Crude ash & 104 & 110 & 79 \\
\hline Starch $^{1}$ & 110 & 66 & \\
\hline Crude fat & & & 31 \\
\hline $\mathrm{CP}(N \times 6.25)$ & 159 & 167 & 173 \\
\hline Crude fibre & & & 198 \\
\hline NDF & 364 & 371 & 371 \\
\hline ADF & 199 & 234 & 304 \\
\hline$A D L$ & 43 & 84 & 120 \\
\hline Gross energy (MJ/kg) & 16.1 & 16.4 & 16.5 \\
\hline \multicolumn{4}{|l|}{ Tannins } \\
\hline Total tannins ${ }^{2}$ & 1.03 & 1.82 & 4.92 \\
\hline 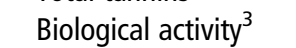 & $\mathrm{Na}$ & 10.60 & 33.77 \\
\hline
\end{tabular}

${ }^{1}$ values calculated from tabulated data.

${ }^{2} \%$ Equivalent tannic acid; for sainfoin, total tannins are equal to condensed tannins.

${ }^{3}$ Protein precipitation activities $\left(\mathrm{cm}^{2} / \mathrm{g}\right)$.

experiment and twice a week after 21 days DPI. The faecal worm egg counts (FECs, expressed as eggs per gram (EPG) of fresh faeces) were assessed on each cage sample based on the modified McMaster technique. The total faecal excretion was weighed once a week to determine the total faecal worm egg output. Faecal DM was determined during the digestibility trial. On DPI $39,75 \mathrm{~g}$ of faeces of each cage from the two infected groups were stored for 10 days at $23^{\circ} \mathrm{C}$ in humid conditions in order to allow egg hatching and to calculate the rate of larval development. The larvae were extracted from the faeces with a Baermann apparatus for $6 \mathrm{~h}$ and then counted. The number of larvae was extrapolated to the total amount of cultured faeces and divided by the number of total faecal eggs in order to calculate the egghatching rate. Finally, the rabbits were euthanized on DPI 45. The small intestines were individually collected and identified, as well as faecal samples in the distal colon. The small intestines were then opened and washed to collect digesta on a $100-\mu \mathrm{m}$ sieve. The adult worms were counted for each rabbit based on a $10 \%$ aliquot method, and males and females were identified. The survival rate $(\%$ of the initial dose of larvae) was estimated by dividing the number of total adult worms by the given number of infective larvae. After cleaning the worms with lactophenol, the number of eggs contained in utero (female fecundity) was also determined on 10 female worms/rabbit by direct counting under microscopic examination.

\section{Statistical analysis}

All data were analysed using R software. Normality was checked with the Shapiro-Wilk test or the D'AgostinoPearson test in the presence of ex aequo. An ANOVA on repeated measurements was performed on FEC values after being $\log (n+1)$-transformed. Wilcoxon and Kruskal-Wallis tests were performed on FEC values when normality could not be obtained by logarithmic transformation. Faecal egg count at slaughter, the number of adult worms in the intestine and fecundity values were analysed using $T$-tests, and animal performances were analysed using a two-way ANOVA. Ratios were analysed using a $\chi^{2}$ test. As $T$. colubriformis is not a usual parasite of rabbit and due to some difficulties during individual infection, 10 rabbits (out of 32) were negative with regard to infection (five in each infected group) and were thus excluded from the statistical analysis.

\section{Results}

Feed intake and growth performances

There were no significant interactions between the diet and infection effects, regardless of the parameter analysed. On average, a rabbit in the sainfoin groups ingested $110 \mathrm{~g}$ of feed/day, corresponding to $1.8 \mathrm{~g}$ of tannins (tannic acid equivalent (TA eq.)) per day, whereas a rabbit from the control groups ingested $105 \mathrm{~g}$ of feed, corresponding to $0.9 \mathrm{~g}$ of TA eq. per day; Table 2). The feed intake was not significantly affected by the infection. Among the four groups and during the whole experiment (6 weeks), the rabbits did not show any sign of degraded health status (no signs of diarrhoea). Accordingly, from weaning to slaughter, there was no mortality or morbidity, even in the infected groups. Disregarding the infection status, the live weight and growth were similar between all groups, although the growth tended $(P=0.06$; Table 2$)$ to be $3 \%$ lower in the $S$ groups (IS, NIS). The feed intake was $5 \%$ higher in the sainfoin groups compared with the control groups $(+5.2 \mathrm{~g} \mathrm{DM} /$ day; $P<0.01)$. Accordingly, the feed conversion ratio was $10 \%$ higher for the sainfoin groups compared with the control groups (3.2 v. $2.9 ; P<0.001)$.

\section{Digestibility and nutritive value of sainfoin}

The digestibility of organic matter averaged $65.8 \%$ in accordance with classical values recorded for such a diet. There was no impact either of the diet or of the infection on organic or energy digestibility (Table 3). Conversely, the digestive efficiency of protein was reduced by six units (\%) in both 'sainfoin groups' (NIS and IS) compared with the control groups $(P<0.001)$. Digestibility coefficients for hemicelluloses were 
Table 2 Effect of infection and diet on growth performance in growing rabbits

\begin{tabular}{|c|c|c|c|c|c|c|c|c|c|}
\hline & \multirow[b]{2}{*}{$n$} & \multicolumn{4}{|c|}{ Groups } & \multirow[b]{2}{*}{ RMSE } & \multicolumn{3}{|c|}{$P$ value } \\
\hline & & IC & IS & $\mathrm{NIC}$ & NIS & & Inf. $\times$ diet & Inf. & Diet \\
\hline Live weight D0 (g) & 64 & 625 & 641 & 624 & 635 & 69 & 0.89 & 0.84 & 0.43 \\
\hline Live weight D45 (g) & 64 & 2419 & 2391 & 2492 & 2392 & 150 & 0.34 & 0.34 & 0.10 \\
\hline Weight gain from D0 to D42 (g/day) & 64 & 38.8 & 38.2 & 40.2 & 38.2 & 2.6 & 0.30 & 0.27 & 0.06 \\
\hline Feed intake from D0 to D42 (g DM/day) & 32 & $103.1^{\mathrm{a}}$ & $110.1^{\mathrm{b}}$ & $106.0^{\mathrm{ab}}$ & $109.5^{\mathrm{b}}$ & 7.1 & 0.33 & 0.51 & * \\
\hline Feed conversion ratio & 32 & $2.93^{\mathrm{a}}$ & $3.20^{\mathrm{b}}$ & $2.90^{\mathrm{a}}$ & $3.19^{b}$ & 0.21 & 0.92 & 0.71 & *** \\
\hline
\end{tabular}

IC = infected control diet; IS = infected sainfoin diet; NIC = non-infected control diet; NIS = non-infected sainfoin diet; RMSE = root mean square of the error that applies to the statistical model; Inf. = infection; DM = dry matter.

a,b Values within a row with different superscripts differ significantly at $P<0.05$.

${ }^{*} P<0.05,{ }^{* * *} P<0.01$.

Table 3 Effect of infection and diet on the digestibility coefficient in growing rabbits

\begin{tabular}{|c|c|c|c|c|c|c|c|c|}
\hline & \multicolumn{4}{|c|}{ Groups } & \multirow[b]{2}{*}{ RMSE } & \multicolumn{3}{|c|}{$P$ value } \\
\hline & IC & IS & $\mathrm{NIC}$ & NIS & & Inf. $\times$ Diet & Inf. & Diet \\
\hline \multicolumn{9}{|l|}{ Digestibility coefficient (\%) } \\
\hline Dry matter & 65.1 & 66.3 & 66.3 & 67.6 & 1.8 & 0.90 & 0.10 & 0.11 \\
\hline Organic matter & 65.3 & 65.2 & 66.3 & 66.3 & 1.9 & 0.90 & 0.21 & 0.98 \\
\hline$C P$ & $76.5^{\mathrm{a}}$ & $70.2^{b}$ & $75.3^{\mathrm{a}}$ & $69.6^{\mathrm{b}}$ & 3.1 & 0.82 & 0.43 & *** \\
\hline Energy & 64.4 & 64.7 & 65.2 & 65.7 & 2.1 & 0.94 & 0.34 & 0.62 \\
\hline NDF & 39.7 & 42.2 & 42.0 & 44.4 & 3.7 & 0.98 & 0.15 & 0.62 \\
\hline ADF & 31.5 & 37.5 & 33.4 & 36.9 & 4.5 & 0.52 & 0.72 & 0.23 \\
\hline Hemicelluloses (NDF-ADF) & $49.6^{\mathrm{ab}}$ & $45.3^{\mathrm{b}}$ & $52.6^{\mathrm{ab}}$ & $52.8^{\mathrm{a}}$ & 4.7 & 0.24 & * & 0.35 \\
\hline \multicolumn{9}{|l|}{ Nutritive value of the diets } \\
\hline Digestible energy (MJ/kg as fed) & 10.37 & 10.63 & 10.49 & 10.78 & 0.35 & 0.93 & 0.32 & 0.07 \\
\hline Digestible protein (g/kg as fed) & 76.2 & 73.1 & 75.0 & 72.5 & 3.1 & 0.83 & 0.47 & 0.07 \\
\hline \multicolumn{9}{|c|}{ Nutritive value of the sainfoin as raw material ${ }^{1}$} \\
\hline Digestible energy ( $\mathrm{MJ} / \mathrm{kg}$ as fed) & & 11.03 & & 11.21 & & & 0.54 & \\
\hline Digestible protein ( $\mathrm{g} / \mathrm{kg}$ as $\mathrm{fed}$ ) & & 110 & & 110 & & & 0.75 & \\
\hline
\end{tabular}

IC = infected control diet; IS = infected sainfoin diet; NIC = non-infected control diet; NIS = non-infected sainfoin diet; RMSE = root mean square of the error that applies to the statistical model; Inf. = infection.

a,b Values within a row with different superscripts differ significantly at $P<0.05$, according to a one-way ANOVA.

${ }^{1}$ Calculated by the difference between $\mathrm{C}$ and $\mathrm{S}$ diets.

${ }^{*} P<0.05,{ }^{* *} P<0.01$.

reduced by $10 \%$ in infected animals compared with non-infected ones $(-5$ points; $P<0.05)$.

Pelleted dehydrated sainfoin was substituted at the level of $39.6 \%$ for alfalfa in the two sainfoin diet groups. Based on the results of the non-infected group, the $D E$ concentration of the dehydrated sainfoin was calculated as $11.2 \mathrm{MJ} / \mathrm{kg}$ as fed, and DPs as $110 \mathrm{~g} / \mathrm{kg}$ as fed in the raw material. These values were calculated with no significant difference in the infected groups (Table 3).

\section{Measurements of the parasitological effects}

The kinetics of FEC (Figure 1) indicated that the infection was successful in 22 out of 32 rabbits. The mean values of FEC (excluding the zero values) ranged between 100 and $400 \mathrm{EPG}$, and the variability between samples was high $( \pm 200$ EPG). The results of the ANOVA on repeated measurements did not show any overall difference in EPG between the two infected groups (IC v. IS). A difference was only observed on DPI 32 when FEC in the IC group was significantly lower than in the IS group $(P=0.026$; Figure 1$)$. Considering the whole experimental period, no difference was observed between the IC and IS groups (on average, $258 \mathrm{EPG} ; P=0.57$ ). On DPI 45, the mean egg counts from individual faeces collected directly in the distal colon were reduced by more than $30 \%$ in the IS group compared with the IC group, but the difference was not significant $(P=0.20)$. The same observations (lack of difference) applied to the total faecal egg output (20558 eggs; $P=0.25$ ), and on FEC expressed in EPG of faecal DM (168 eggs; $P=0.75$ ).

After slaughter (DPI 45), the number of adult $T$. colubriformis recovered in the small intestine (972) did not differ between the IC and IS groups ( $P=0.50$; Table 4). Overall, the survival rate of the infective larvae of $T$. colubriformis was higher than $40 \%$ in the 10-week-old experimentally infected rabbits (the rabbits that were negative with regard to infection were excluded). The number of eggs in utero per female worm (13.8) was similar in both groups $(P=0.83)$. In contrast, the rate of eggs hatched in the sainfoin-fed group tended to be lower than for the controlfed group (58.3\% v. 85.2\%; $P=0.08)$. 
Throughout the whole experiment, no coccidian oocysts were detected using a modified McMaster technique for all groups, nor were any other propagules detected in samples of non-infected groups.

\section{Discussion}

The aim of our study was to evaluate the nutritive value of dehydrated sainfoin and its potential use as a nutraceutical for rabbits. We will first discuss the results obtained on the nutritive value of sainfoin and the effects on digestion and performance for the growing rabbit by analysing the effect of alfalfa replacement by this legume in a pelleted balanced diet. We will then discuss the effects of sainfoin intake on different parameters that characterise experimental infection of rabbits with $T$. colubriformis.

\section{Sainfoin as an alternative to alfalfa in rabbit feed}

Effect of sainfoin dietary incorporation on digestion and performance. The higher feed intake observed with the sainfoin diet suggested a high palatability of this product for growing rabbits. This higher intake could be related to the twofold higher lignin concentration of the S diet (8\%) when compared with the control. The lower digestion of proteins in the sainfoin group ( -6 points compared with control values) could be explained by the effect of tannins in the small intestine, although this has never been quantified for the

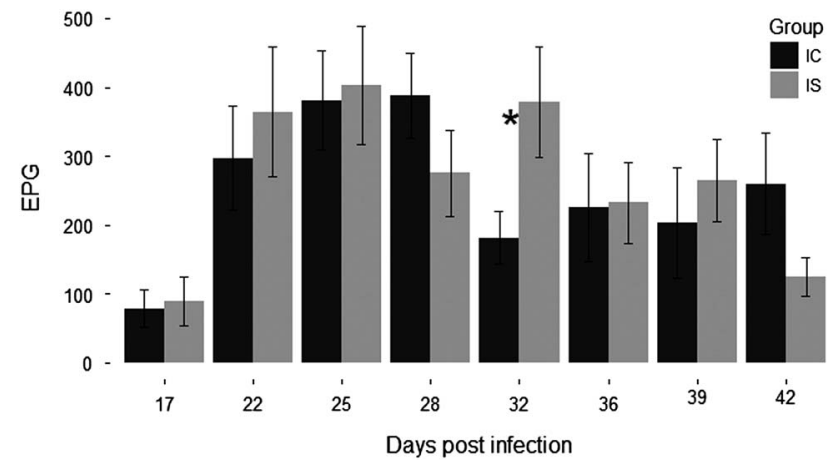

Figure 1 Comparison of means of faecal egg counts on eggs per gram (EPG) in infected groups fed with control diet - IC (black) - or sainfoin diet - IS (grey). Error bars indicate standard errors. ${ }^{*} P<0.05$. growing rabbit. It is suspected that proteins are bound with tannins in the range of intestinal $\mathrm{pH}$ and might therefore be less available for digestive processes. Accordingly, the DP intake tended to be less in the two sainfoin groups than in the two control groups $(-7.9 \mathrm{~g} \mathrm{DP} /$ day/rabbit; $\mathrm{P}=0.07)$. This could explain that rabbits fed with the control diet tended to grow faster $(+3.3 \%$; $P=0.06)$ even though the $D E$ content of sainfoin was higher. Moreover, consideration must be given to the fibre intake of the rabbits and, particularly, to a twofold higher lignin intake for $S$ groups compared with control ones (9.2 v. $4.5 \mathrm{~g} \mathrm{ADL} /$ day). As shown by Perez et al. (1994), a high lignin intake could explain the poorer feed conversion ratio observed in the NIS and IS rabbits even though their DE intake was higher than in the $\mathrm{C}$ and IC groups.

Nutritive value of sainfoin. The nutritive value observed for the dehydrated and pelleted sainfoin was high, as the DE content reached $12.97 \mathrm{MJ} / \mathrm{kg} \mathrm{DM}$ and $128 \mathrm{~g}$ of DP/kg DM. For a sainfoin hay (incorporated into a pelleted diet) containing a high NDF level (55\%), Fernández-Carmona et al. (1996) reported a $35 \%$ lower level of DE (8.2 MJ/kg DM) and a 50\% lower DP content ( $62 \mathrm{~g} / \mathrm{kg} \mathrm{DM}$ ) measured in 4 to 5 -month-old rabbits (3 to $4 \mathrm{~kg}$ live weight (LW)). Similarly, Liu et al. (1992) reported a DE of $8.5 \mathrm{MJ} / \mathrm{kg}$ DM for a sainfoin hay fed to adult angora rabbits. This considerable difference in nutritive values between hay and dehydrated sainfoin could be explained by several factors such as the delay in harvesting time or variations in plant physiological stages. Moreover, dehydrating legumes led to a better conservation of nutritive compounds when compared with conversion to hay by reducing the loss of foliage.

The high-fibre and high-DE concentration of dehydrated sainfoin pellets indicated that this raw material is a valuable source of fibre and of energy, comparable with dehydrated alfalfa. In fact, compared with dehydrated alfalfa, sainfoin had a $40 \%$ higher DE content (11.2 v. 7.6 MJ/kg as fed) and a similar DP content (110 v. $113 \mathrm{~g} \mathrm{DP} / \mathrm{kg})$. Therefore, on the basis of the results of our study, dehydrated sainfoin seems to be an excellent trade-off feedstuff to formulate balanced diets for growing rabbits, as it provides large quantities of lignins that are essential for digestive health in rabbits

Table 4 Effect of diet on daily excretion of faecal eggs, egg hatching, survival rate, sex ratio and fecundity of Trichostrongylus colubriformis

\begin{tabular}{lccccc}
\hline \hline & $n$ & IC & IS & RMSE & $P$ value \\
\hline Adult worms in intestine $^{1}$ & 22 & 1016 & 929 & 283 & 0.50 \\
Fecundity (eggs in utero per female) & 220 & 14.4 & 14.0 & 2.9 & 0.95 \\
Total faecal egg output $_{\text {Faecal eggs at slaughter (eggs/g) }}$ & 22 & 29509 & 33515 & 24263 & 0.25 \\
Egg-hatching rate (\%) $^{2}$ & 10 & 473 & 327 & 245.3 & 0.20 \\
\hline \hline
\end{tabular}

IC = infected control diet; IS = infected sainfoin diet; RMSE = root mean square of the error that applies to the statistical model.

${ }^{1}$ Some rabbits were not correctly infested (five for each group) and were thus excluded from the statistical analysis.

${ }^{2}$ Percentage of gastrointestinal nematode eggs in faeces hatching and developing into L3 larvae after 10 days of incubation. 
(Gidenne et al., 2015), whereas its DE and DP contents remain high. Further studies with more moderate incorporation of dehydrated sainfoin (around 20\%) will aim at confirming our initial results.

\section{Sainfoin a potential nutraceutical to control gastrointestinal nematodes in rabbits}

T. colubriformis infections of young weaned rabbits as a model. Wild rabbits are natural carriers of GINs. In OF, grazing rabbits that are potentially exposed to the faeces of wild rabbits can therefore become infected. Among the main GIN species, Graphidium strigosum and Trichostrongylus sp. could impact their condition and health (Schoeb et al., 2007). Consequently, there is the need for an experimental model to study the interactions between GINs and rabbits in order to test alternatives to chemical drugs in OF systems. Regarding the difficulty to obtain $T$. retortaeformis larvae and the availability of $T$. colubriformis larvae, $T$. colubriformis was used. Experimental infection of young weaned rabbits with T. colubriformis has been previously demonstrated (Williams and Palmer, 1964; Hoste et al., 1988). Despite the fact that $T$. colubriformis has the potential to naturally infect rabbits, it remains occasional (Saulai and Cabaret, 1998), with T. retortaeformis being the specific Trichostrongylus species found in rabbits (Audebert et al., 2003). Therefore, in experimental infections in rabbits, the biological traits of $T$. colubriformis can present some variations compared with infections in the usual hosts (small ruminants; Audebert et al., 2003). For example, the mean number of eggs per utero in female worms appeared to be reduced when hosted in rabbits: 14 in our study and 24 eggs per utero in sheep. Despite these limits, $T$. colubriformis infections in young weaned rabbits make it possible to explore sainfoin as a nutraceutical in OF systems, and more widely the opportunity to use rabbits infected with $T$. colubriformis as a model to explore several aspects of the effects of sainfoin and other tannins containing resources on GINs.

Effect of condensed tannins on T. colubriformis. Condensed tannins form stable bindings with proteins in a range of $\mathrm{pH}$ from 4 to 7 (Jones and Mangan, 1977). pH values in the stomach of young rabbits ranged from 1.5 to 2.0, with a maximum of 3.5 in the fundus (in the presence of soft faeces) at the beginning of the day (Blas and Gidenne, 2010). These values seem to be too acidic to enable the formation of stable complexes of CT-proteins in the stomach. $\mathrm{pH}$ values are higher in the small intestine: from 6.4 to 7.2 ; in the caecum: 6.0; and in the colon: 6.5. Therefore, it is more likely that CTs might bind with proteins in the intestines. Exsheatment of $T$. colubriformis infective larvae occurs in the compartment anterior (the stomach) to the compartment of adult establishment (the small intestine). Due to low pH values in the rabbit stomach, it is hypothesised that the exsheatment could not be impaired by the formation of complex CT-larval proteins, explaining similar recovery rates in sainfoin $v$. control groups.
Min et al. (2004) suggested that CTs could reduce helminth fecundity rather than survival of worms in the digestive tract. In sheep, the required amount of tannin in the diet necessary to trigger anthelminthic activity in ruminants has been evaluated at approximately 30 to $40 \mathrm{~g}$ of CTs $/ \mathrm{kg}$ DM (3\% to 4\%; Hoste et al., 2006). In our sainfoin diet, the level of CT attained was only $16.4 \mathrm{~g} / \mathrm{kg} \mathrm{DM}$, and it might have been insufficient to impair larvae establishment and/or worm fecundity. However, at the end of the experiment (at slaughter) and when feed intake was higher, we observed that FEC values were higher by $30 \%$ in the control group compared with the sainfoin group.

The levels of CTs in the sainfoin diet appeared to have been sufficient to affect the development of eggs into larvae, as demonstrated by our results. In horses fed with a diet containing 3.6\% of CTs/kg DM, Collas et al. (2015) reported similar effects. The FECs were not reduced but the rate of larval development was. The mode of action of CTs on worm eggs could be either direct or indirect. Molan et al. (1999) suggested that the direct effect could be linked to the exposure of eggs to CTs during their development, as CTs are not absorbed from the digestive tract and remain in the faeces. However, the hypothesis of an indirect effect of CTs based on antibacterial activity could be also raised. As shown by Wang (1970), Escherichia coli is the suitable bacteria for feeding the free-living stage (L1 and L2) of $T$. colubriformis and for favouring their development into L3 larvae. Min et al. (2007) determined a dose-dependent activity of tannins to reduce a faecal population of $E$. coli in steers, with an intermediate effect at $0.75 \%$ and a maximum effect at $1.5 \%$ (corresponding to 7.5 and $15 \mathrm{~g} \mathrm{DM}$ of tannins/day). Methanogens bacteria could be also inhibited by CTs of pine bark in goats (Min et al., 2014). Dalle Zotte and Cossu (2009) also reported bactericidal activity on $E$. coli in the caecum of rabbits supplied with $1 \%$ or $3 \%$ of quebracho tannin extract. More largely, the use of tannin extract seems to reduce the rabbit mortality and morbidity in an enteropathy infected environment (Maertens and Struklec, 2006). In the current experiment, the level of tannins in the sainfoin diet $(1.65 \%)$ compared with the control diet $(0.95 \%)$ could be responsible for the decrease in the $E$. coli and other bacteria population and could therefore indirectly explain the reduced development of eggs into larvae. However, the tannins are widespread in plants, thus the difference in tannin content of the control and sainfoin-contained diet was rather small.

Besides, as the sainfoin also contains lectins (such concanavalin A), we also hypothesise that these molecules might have an impact on $T$. colubriformis infection, as shown in sheep (Rios de Alvarez et al., 2010). This should be further studied in the rabbit.

\section{Effect of infection}

Musongong et al. (2004) described a dose-dependent effect on BW in T. colubriformis-infected rabbits. The infection with a medium dose of infective larvae of $T$. colubriformis $(3000$ $\mathrm{L} 3 / \mathrm{kg} \mathrm{LW}^{0.75}$ ) in our experiment did not result in any significant difference in BW or growth between animals infected 
or not. Purvis and Sewell (1971) also indicated that the number of eggs excreted by rabbits was higher when it resulted from an infective dose of larvae obtained from rabbits than from the same dose of larvae obtained from sheep. Purvis and Sewell (1971) also indicated that egg excretion is higher at the $3^{\text {rd }}$ or the $7^{\text {th }}$ generation of rabbits. Therefore, in future experiments, it might be worth using infective larvae of $T$. colubriformis directly obtained from $2^{\text {nd }}$-generation rabbits in order to maximise the possible difference in egg excretion, or to use nematodes adapted to rabbits.

The resilience of the infected animals could be due to higher feed consumption. In our experiment, infected animals do not show a higher feed consumption than noninfected ones. However, feed was designed to cover all the rabbits' needs. We therefore considered that the nutritional level was optimal. In such conditions, it would have been difficult to make any improvement based on nutrition, as suggested by Hoste et al. (2016). Moreover, at weaning, our rabbits were free of the major pathogens (enteropathogenic E. coli) and free of coccidia. This could also explain the lack of impact of the infection on growth and intake.

However, the infection with $T$. colubriformis impaired the digestion of hemicelluloses that are considered to be highly digested by the rabbit (when compared with cellulose). The main hemicelluloses of dicotyledonous plants (both alfalfa and sainfoin) are xyloglucans. A consequence of gastrointestinal parasitism is the possible negative interaction for fibre digestion, possibly explained by changes both of microbiota and of the biochemical environment of the gut induced by parasites (Hoste, 2001). T. colubriformis develop in the proximal part of the small intestine in rabbits (Hoste et al., 1988). In contrast, the digestion of fibres predominantly occurs in the caecum. However, as there is also some activity of xylanases in the small intestine (De Blas et al., 1999), the digestion of hemicelluloses may begin in the small intestine (Gidenne and Ruckebusch, 1989). Hence, the presence of $T$. colubriformis in the small intestine might be responsible to some extent for a lower bacterial hemicellulase activity.

\section{Pelleting process and biological activity of tannins}

The biological activity on BSA of the sainfoin diet was lower than expected by $21 \%$, based on the results of the raw material $\left(10.6 \mathrm{v} .13 .5 \mathrm{~cm}^{2} / \mathrm{g}\right)$. On the basis of our results, it seems that the protein precipitation activity of tannins contained in sainfoin was reduced by the pelleting process. However, Terrill et al. (2007) found that the pelleting of Sericea lespedeza (another tannin-containing legume) did not impact the anthelmintic properties and even improved them. Nevertheless, in Terrill et al. (2007), the temperature did not exceed $70^{\circ} \mathrm{C}$ during the process. To prepare the rabbit feed, the pellets were processed at $80^{\circ} \mathrm{C}$ to $85^{\circ} \mathrm{C}$. Therefore, either a threshold between the improvement and the deterioration of $\mathrm{CT}$ activity may exist between $70^{\circ} \mathrm{C}$ and $80^{\circ} \mathrm{C}$, or Sericea lespedeza and sainfoin tannins do not respond in the same way to heating. In further studies, it would be interesting to take the influence of overheating in the pelleting process on the biological activity of tannins into account, and to determine a maximum temperature to maximise anthelmintic properties.

To conclude, on the basis of this first study, dehydrated sainfoin pellets seem to be an interesting feedstuff for growing rabbits and could constitute a real alternative to dehydrated alfalfa as its DE content is higher than alfalfa $(11.12 \mathrm{MJ} / \mathrm{kg}$ as fed), whereas its DP content is similar to alfalfa ( $110 \mathrm{~g} / \mathrm{kg}$ as fed). It is also an excellent source of fibre as well as a considerable supply of lignins. Moreover, sainfoin could reduce the development of $T$. colubriformis eggs into larvae through the activity of CTs in faeces, therefore limiting environmental contamination.

As recently revealed by Saratsis et al. (2016) in lambs, condensed sainfoin tannins may also have an effect on coccidia. This will have to be examined in growing rabbits as coccidiosis is a major concern in this species. Moreover, trials conducted on an experimental organic rabbit farm are being analysed to assess, in situ under natural infections on pasture, the impact of grazing fresh sainfoin. These different studies will help to improve our understanding of the effects of sainfoin as a nutraceutical in rabbit production.

\section{Acknowledgements}

This work was funded by the INRA metaprogram GISA (PROF project) and INRA-AgriBio4 (CuniPat project). The authors thank the MG2Mix (Chateaubourg, France) and Multifolia (Viapres Le Petit, France) companies for providing the dehydrated sainfoin pellets, the UE INRA PECTOUL for providing rabbits (E. Balmisse and V. Helies) and experimental diets (M. Moulis), and Dr S. Sotiraki from the Veterinary Research Institute of Thessaloniki (HAO, Greece) for providing the infective larvae of $T$. colubriformis. The authors thank all of the colleagues involved in data collection and analysis, especially C. Lacassagne (INRA, ToxAlim) and C. Bannelier (INRA, GenPhySE).

\section{References}

Audebert F, Cassone J, Kerboeuf D and Durette-Desset MC 2003. Development of Trichostrongylus colubriformis and Trichostrongylus vitrinus, parasites of ruminants in the rabbit and comparison with Trichostrongylus retortaeformis. Parasitology Research 90, 57-63.

Blas $E$ and Gidenne T 2010. Digestion of sugars and starch. In Nutrition of the rabbit (ed. C De Blas and J Wiseman), pp. 19-38. CABI Publishing, Wallingford, UK.

Collas C, Salle G, Dumont B, Cabaret J, Cortet J, Martin-Rosset W, Wimel L and Fleurance G 2015. Quelle efficacité d'un apport de sainfoin (Onobrychis viciifolia) ou d'un excès d'azote de courte durée dans l'alimentation du cheval pour lutter contre les strongles digestifs? In Proceedings of the 41th Journée de la Recherche Equine, 12 March, Paris, France, pp. 158-161.

Dalle Zotte A and Cossu ME 2009. Dietary inclusion of tannin extract from red quebracho trees (Schinopsis spp.) in the rabbit meat production. Italian Journal of Animal Science 8, 784-786.

De Blas C, Garcia J and Carabaño R 1999. Role of fibre in rabbit diets. A review. Annales de Zootechnie 48, 3-13.

Fernández-Carmona J, Cervera C and Blas E 1996. Prediction of the energy value of rabbit feeds varying widely in fibre content. Animal Feed Science and Technology 64, 61-75. 
Gidenne T, Lebas F, Savietto D, Dorchies P, Duperray J, Davoust $C$ and FortunLamothe $L$ 2015. Nutrition et alimentation. In Le lapin. De la biologie à l'élevage (ed. T Gidenne), pp. 152-196. Quae éditions, Paris, France.

Gidenne T and Ruckebusch $Y$ 1989. Flow and rate of passage studies at the ileal level in the rabbit. Reproduction Nutrition Development 29, 403-412.

Hagerman AE and Butler LG 1978. Protein precipitation method for the quantitative determination of tannins. Journal of Agricultural and Food Chemistry 26, 809-812.

Hoste H 2001. Adaptive physiological processes in the host during gastrointestinal parasitism. International Journal for Parasitology 31, 231-244.

Hoste H, Jackson F, Athanasiadou S, Thamsborg SM and Hoskin SO 2006. The effects of tannin-rich plants on parasitic nematodes in ruminants. Trends in Parasitology 22, 253-261.

Hoste H, Kerboeuf D and Parodi AL 1988. Trichostrongylus colubriformis : effects on villi and crypts along the whole small intestine in infected rabbits. Experimental Parasitology 67, 39-46.

Hoste H, Torres-Acosta JFJ, Quijada J, Chan-Perez I, Dakheel MM, Kommuru DS, Mueller-Harvey I and Terrill TH 2016. Interactions between nutrition and infections with Haemonchus contortus and related gastrointestinal nematodes in small ruminants. In Haemonchus contortus and haemonchosis - past, present and future trends (ed. BG Robin and S-H Georg Von), pp. 239-351. Academic Press, New York, NY, USA.

Hoste H, Torres-Acosta JFJ, Sandoval-Castro CA, Mueller-Harvey I, Sotiraki S, Louvandini H, Thamsborg SM and Terrill TH 2015. Tannin containing legumes as a model for nutraceuticals against digestive parasites in livestock. Veterinary Parasitology 212, 5-17.

Jones WT and Mangan JL 1977. Complexes of the condensed tannins of sainfoin (Onobrychis viciifolia scop.) with fraction 1 leaf protein and with submaxillary mucoprotein, and their reversal by polyethylene glycol and $\mathrm{pH}$. Journal of the Science of Food and Agriculture 28, 126-136.

Liu SM, Zhang L, Chang C, Pen DH and Xu Z 1992. The evaluation of nutritive values of the feedstuffs and diets for Angora rabbits. 1. The determination of the contents of digestible energy and digested crude protein in feedstuffs. In 5th World Rabbit Congress, 25-30 July, Corvallis, Oregon, pp. 1633-1639.

Maertens L and Struklec M 2006. Technical note: preliminary results with a tannin extract on the performance and mortality of growing rabbits in an enteropathy infected environment. World Rabbit Science 14, 189-192.

Makkar HPS 2003. Quantification of tannins in tree and shrub foliage. A laboratory manual. Kluwer Academic Publishers, Dordrecht, The Netherlands. Marais JPJ, Mueller-Harvey I, Brandt EV and Ferreira D 2000. Polyphenols, condensed tannins, and other natural products in Onobrychis viciifolia (Sainfoin). Journal of Agricultural and Food Chemistry 48, 3440-3447.

Martin G, Duprat A, Goby J-P, Theau J-P, Roinsard A, Descombes M, Legendre H and Gidenne T 2016. Herbage intake regulation and growth of rabbits raised on grasslands: back to basics and looking forward. Animal 10, 1609-1618.

Min BR, Pinchak WE, Anderson RC and Callaway TR 2007. Effect of tannins on the in vitro growth of Escherichia coli 0157:H7 and in vivo growth of generic Escherichia coli excreted from steers. Journal of Food Protection 70, 543-550.

Min BR, Pomroy WE, Hart SP and Sahlu T 2004. The effect of short-term consumption of a forage containing condensed tannins on gastro-intestinal nematode parasite infections in grazing wether goats. Small Ruminant Research 51, 279-283. Min BR, Solaiman S, Shange R and Eun J-S 2014. Gastrointestinal bacterial and methanogenic archaea diversity dynamics associated with condensed tannin-containing pine bark diet in goats using 16S rDNA amplicon pyrosequencing. International Journal of Microbiology 4, 1-11.
Molan AL, Waghorn GC and McNabb WC 1999. Condensed tannins and gastrointestinal parasites in sheep. Proceedings of the New Zealand Grassland Association 61, 57-61.

Musongong GA, Chiejina SN, Fakae BB and Ikeme MM 2004. The responses of a tropical breed of domestic rabbit, Oryctolagus cuniculus, to experimental infection with Trichostrongylus colubriformis. Journal of Helminthology 78, 249-257.

Paolini V, Fouraste I and Hoste H 2004. In vitro effects of three woody plant and sainfoin extracts on two parasitic stage of three parasitic nematode species. Parasitology 129, 69-77.

Paolini V, Frayssines A, De La Farge F, Dorchies P and Hoste H 2003. Effects of condensed tannins on established populations and on incoming larvae of Trichostrongylus colubriformis and Teladorsagia circumcincta in goats. Veterinary Research 34, 331-339.

Perez JM, Gidenne $T$, Lebas $F$, Caudron I, Arveux $P$, Bourdillon $A$ Duperray J and Messager B 1994. Dietary lignins in growing rabbits. 2 consequences on growth performances and mortality. Annales de Zootechnie 43, 323-332.

Perez JM, Lebas F, Gidenne T, Maertens L, Xiccato G, Parigi-Bini R, Dalle Zotte A, Cossu ME, Carazzolo A Villamide MJ, Carabaño R, Fraga MJ, Ramos MA, Cervera C, Blas EJFC, Falcao E, Cunha $L$ and Bengala Freire J 1995. European reference method for in vivo determination of diet digestibility in rabbits. World Rabbit Science 3, 41-43.

Purvis GM and Sewell MMH 1971. The host-parasite relationship between the domestic rabbit and Trichostrongylus colubriformis. Veterinary Record 89, 151-152.

Rios de Alvarez L, Greer AW, Jackson F, Athanasiadou S, Kyriazakis I and Huntley JF 2010. The effect of dietary sainfoin (Onobrychis viciifolia) on local cellular responses to Trichostrongylus colubriformis in sheep. Parasitology 135 , 1117-1124.

Saratsis A, Voutzourakis N, Theodosiou T, Stefanakis A and Sotiraki S 2016. The effect of sainfoin (Onobrychis viciifolia) and carob pods (Ceratonia siliqua) feeding regimes on the control of lamb coccidiosis. Parasitology Research 115, 2233-2242.

Saulai M and Cabaret J 1998. Limited role of lagomorphs (Oryctolagus cuniculus and Lepus capensis) in the dispersion of parasite nematodes of ruminants. Veterinary Parasitology 77, 301-304.

Schoeb TR, Cartner SC, Baker RA, Gerrity LW and Baker DG 2007. Parasites of rabbits. In Flynn's parasites of laboratory animals (ed. DG Baker), pp. 451-499. Blackwell Publishing Ltd, Oxford, UK.

Terrill TH, Mosjidis JA, Moore DA, Shaik SA, Miller JE, Burke JM, Muir JP and Wolfe $R$ 2007. Effect of pelleting on efficacy of sericea lespedeza hay as a natural dewormer in goats. Veterinary Parasitology 146, 117-122.

Van Soest PJ, Robertson JB and Lewis BA 1991. Methods for dietary fiber, neutral detergent fiber, and non starch polysaccharides in relation to animal nutrition. Journal of Dairy Science 74, 3583-3597.

Villamide MJ, Maertens L, Cervera C, Perez JM and Xiccato G 2001. A critical approach of the calculation procedures to be used in digestibility determination of feed ingredients for rabbits. World Rabbit Science 9, 19-26.

Wang G-T 1970. Suitability of various species of microorganisms as food for the free-living stages of Trichostrongylus colubriformis. The Journal of Parasitology $56,753-758$.

Williams GAH and Palmer BH 1964. Trichostrongylus colubriformis (a nematode of sheep and other ruminants) as a test organism for sheep anthelmintics in the laboratory. Nature 203, 1399-1400. 